\title{
Advances in the understanding of the Toarcian Oceanic Anoxic Event (IGCP-655 annual report)
}

\author{
Matías Reolid ${ }^{1 *}$, Emanuela Mattioli' ${ }^{2,3}$, Luís V. Duarte ${ }^{4}$, and Abbas Marok ${ }^{5}$ \\ ${ }^{1}$ Departamento de Geología, Universidad Jaén, Campus Las Lagunillas sn, 23071 Jaén, Spain; *Corresponding author, \\ E-mail:mreolid@ujaen.es \\ ${ }^{2}$ Université de Lyon, UCBL, ENSL, CNRS, LGL-TPE, F-69622 Villeurbanne, France \\ ${ }^{3}$ Institut Universitaire de France, Paris, France \\ ${ }^{4}$ MARE and Departamento de Ciências da Terra, Polo II Edif Central, Universidade Coimbra 3030-790 Coimbra, Portugal \\ ${ }^{5}$ Department of Earth and Universe Sciences, University of Tlemcen, P.O. Box 119, Tlemcen, Algeria
}

\section{Introduction}

The study of catastrophic events that affected past marine ecosystems provides us the unique opportunity to establish models which can be applied to ongoing environmental changes and to understand future evolution of the biotas. The growing interest of the society for the ongoing and potential future environmental changes attests for the value represented by the analysis of past climatic changes. In the case of the Toarcian Oceanic Anoxic Event (T-OAE, Early Jurassic; 182 Ma), a dramatic change of marine ecosystems related to massive extinction has been documented in several areas around the world. The Pliensbachian-Toarcian transition and the T-OAE are two global episodes recording worldwide palaeoenvironmental perturbations (Jenkyns, 1988; Jenkyns and Clayton, 1997; Hesselbo et al., 2007). The end of the Pliensbachian regression is followed by a transgression occurring in the Early Toarcian (Haq et al., 1987; de Graciansky et al., 1999). This transgression was also coeval with a widespread deposition of black shales (Jenkyns, 1988), a global warming (García Joral et al., 2011; Korte and Hesselbo, 2011; Suan et al., 2011), and perturbations of the carbon cycle indicated by a negative carbon isotopic excursion (CIE) documented in both marine and terrestrial material (Jenkyns and Clayton, 1986; Schouten et al., 2000; Hesselbo et al., 2007; Al-Suwaidi et al., 2010; Caruthers et al., 2011; Izumi et al., 2012; Reolid, 2014).

An important second-order mass extinction mainly of benthic organisms is documented at the Pliensbachian/Toarcian boundary and in the Polymorphum (= Tenuicostatum)/Levisoni (= Serpentinum) zones boundary (Little and Benton, 1995; Aberhan and Fürsich, 2000; Vörös, 2002; Cecca and Macchioni, 2004; Wignall et al., 2005; Gómez and Goy, 2011; Danise et al., 2013; Caruthers et al., 2014; Ullman et al., 2014; Rita et al., 2016). This extinction was probably driven by oxygen-depletion affecting platforms and oceanic deep environments of Boreal and Tethys domains (Röhl et al., 2001; Bucefalo Palliani et al., 2002; Wignall et al., 2005; Hermoso et al., 2009; Reolid et al., 2012; Rita et al., 2016).

A multidisciplinary, integrated analysis of the T-OAE from stratigraphic successions outcropping in various settings all over the world and the need for taking into account biotic (microfossils, macroinvertebrates and vertebrate assemblages) and abiotic data (sedimentology, cyclostratigraphy, mineralogy, elemental geochemistry, organic geochemistry and isotopic geochemistry) makes the development of an international framework essential by involving researchers from different countries and having different scientific skills. The IGCP-655 project of the IUGS-UNESCO constitutes this international framework where researchers with different disciplinary fields collaborate and share conceptual advances.

Our project aims to investigate the climatic changes related to the sea-level rise, carbon cycle perturbation, sea water acidification, global warming and second-order mass extinction occurred at the Pliensbachian/Toarcian boundary and during the T-OAE. This goal will be achieved through the analysis of rock and fossil records from Algeria, Argentina, Canada, England, France, Germany, Greece, Italy, Iran, Japan, Morocco, North Siberia, Portugal, South China, Spain and Switzerland. Through detailed studies of Upper Pliensbachian to Middle Toarcian biostratigraphy, ichnology, palaeoecology, ecostratigraphy, sedimentology, mineralogy, geochemistry, biogeochemistry and cyclostratigraphy in the cited regions, this project is attempting to document the collapse of the global marine ecosystems and their subsequent recovery. The mechanisms related to the biotic response of various fossil groups (calcareous nannofossils, radiolarians, foraminifera, ostracods, dinoflagellates, bivalves, brachiopods, ammonites, and vertebrates) to climate and environmental adverse conditions will be apprehended. IGCP-655 also try to reconstruct the Early Jurassic oceanic and climatic conditions and investigate feed-back effects between carbon cycle perturbation and global warming as well as compare and correlate all the acquired data in a global stratigraphic framework.

To summarize, the main goals of this project are:

(1) To unravel the impact of carbon cycle perturbation and the related global warming and oxygen depletion on marine ecosystems and productivity.

(2) To elucidate the causes triggering this environmental change.

(3) To clarify the initial phases of the biotic crisis and the factors controlling the biotic recovery for organisms at different trophic levels, from various habitats and climate zones. A special attention will be devoted to the adaptation strategies of opportunist and specialist organisms during the surviving and extinction phases (e.g., Lilliput effect, Lazarus effect, resilience, among others).

These objectives will be attained mainly by collaborative fieldwork in reference Pliensbachian to Toarcian successions, including the Lower Toarcian GSSP (Rocha et al., 2016), and related laboratory work. The IGCP-655 is a project including 98 researchers from 64 research centres corresponding to 25 countries. As a result, the IGCP- 
655 and workshops organized provide a friendly platform for participants to communicate their own research results and also bring together global experts, and research facilities to solve a truly global-scale problem.

\section{Main Advances on the T-OAE during 2017}

The T-OAE is recognized as one of the most important environmental perturbations of the Mesozoic, with a dramatic impact on marine biota revealed by a significant mass extinction event in benthic and pelagic groups (e.g., Wignall et al., 2005). Still, questions regarding the mechanisms involved, the major environmental changes affecting biotas, the global scale and the synchronism remain unresolved. There is no general consensus about the causes or triggering mechanisms of the T-OAE, including the massive enrichment of isotopically light carbon and its transfer between the different reservoirs (e.g., Hesselbo et al., 2000; Kemp et al., 2005), or the production of thermogenic methane during the concomitant intrusive eruption of the Karoo-Ferrar province (e.g., McElwain et al., 2005). Several environmental changes may have been involved in the mass extinction event, such as generalized anoxia, the enhancement of greenhouse conditions and a severe warming, or the incidence of sea-level changes (e.g., Hallam, 1987; McArthur et al., 2000; Bailey et al., 2003; Ghadeer and Macquaker, 2011; Gómez and Goy, 2011; Reolid et al., 2012; Rita et al., 2016; among others). Originally, the T-OAE was considered as a global phenomenon, based on the apparently simultaneous deposition of organic-rich facies in many localities around world (Jenkyns, 1988). However, recent studies point to a significant geographical variability of the event and to the incidence of local or regional-scale processes influencing marine (McArthur et al., 2008; Rodríguez-Tovar and Uchman, 2010; Reolid et al., 2018) and terrestrial environments (e.g., Rodrigues et al., 2016; Baker et al., 2017). It is especially relevant the advance in our knowledge of the different phases of extinction and recovery of ecosystems and the survival strategies to this event.

The contributions of the members of the IGCP-655 during the first year of activity, 2017, have improved our understanding of the T-OAE. Most of these advances were presented in the $1^{\text {st }}$ International Workshop on the T-OAE (October, 4- $7^{\text {th }} 2017$, Jaén) and published in the Abstract Book of this meeting (Reolid (ed.), 2017). The major advances can be summarized in different research topics:

\section{Sedimentology and Stratigraphy}

The analysis of sedimentary successions of the PliensbachianToarcian, including the black shales facies, is an important tool for interpreting environmental conditions and eustatic changes and constitutes the framework for analyzin palaeontological and geochemical data. Some studies have shown the frequence of tempestite deposits during the Early Toarcian in areas such as the South Iberian Palaeomargin (Molina et al., 2017) and the Tibetan Carbonate Platform (Han et al., 2017). The increase of storm deposits during the T-OAE emphasizes the close link between carbon-forced global warming and tropical cyclones.

The analysis of mineral resources has focused on the Mn-carbonate ore deposits from Hungary (Molnar et al., 2017). Moreover the presence of celestine concretions with anomalous high $\delta^{34} \mathrm{~S}$ in the South Iberian Palaeomargin has been interpreted as precipitation in cold seeps. Bruneau et al. (2017) have worked on 3D stratigraphic numerical models for prediction of organic-rich deposits.

Cyclostratigraphic studies have been applied to Iberian Range (Val et al., 2017), High Atlas (Martinez et al., 2017) and Wales (Ruhl et al., 2017) with special emphasis on the orbital chronology. Ruhl et al. (2017) compare the high-precision numerical time-scale for the Early Toarcian with the Karoo-Ferrar volcanism and observe the negative CIE was not a direct consequence of volcanic carbon release.

\section{Incidence of the T-OAE on Marine Communities}

Some works have focused on the analysis of benthic microfossils. Soulimane et al. (2017a, b) have analyzed the turnover of ostracod assemblages at the Pliensbachian-Toarcian transition and at the TOAE in the Southwestern Tethys, including North Gondwana and South Iberian palaeomargins. The study of diversity and composition of foraminiferal assemblages is a valuable tool to approach palaeoenvironmental conditions during the Toarcian biotic crisis (e.g., Rita et al., 2016). The analysis of foraminiferal morphogroups has been used with very good results on the North Siberian and North Algeria Toarcian outcrops (Glinskikh et al., 2017; Sebane and Touahria, 2017) for characterizing low oxygen conditions at the beginning of the Toarcian. Herrero (2017) has evidenced a step-wise extinction of benthic foraminifera in the Iberian Range during the Early Toarcian from outcrops where neither black shales not foraminifera mass extinction are recorded.

The analysis of calcareous nannofossils and the relationship with the carbonate production, palaeoceanography and trophic regime during the T-OAE, has been studied by Ferreira et al. (2017) and Visentin et al. (2017). Based on the Lusitanian Basin record, Correia et al. (2017a, b) discussed the palynological response to the T-OAE, with a particular emphasis on dinoflagellates. In addition, phytoplankton community dynamics have been deduced from high-resolution biomarker analyses (Ruebsam and Schwark, 2017).

There are significant advances on the incidence of the T-OAE on the macroinvertebrate communities (e.g., Baeza-Carratalá et al., 2017; Caswell and Frid, 2017; Martindale and Aberhan, 2017; Monarrez et al., 2017; Posenato et al., 2017). Brachiopods and bivalves have been the main studied groups. Baeza-Carratalá et al. (2017) expose an interesting example of adaptive strategies of brachiopods during the T-OAE from the study of a deep-water brachiopod, resilient assemblage from Spain.

Many works have focused on the body size trends of organisms at the Early Toarcian extinction event, as for belemnites (Rita et al., 2017a), brachiopods and bivalves (Piazza et al., 2017), benthic foraminifera (Rita et al., 2017b) and calcareous nannofossils (Ferreira et al., 2017).

Ichnological analyses are especially interesting due the potential of trace fossils for interpreting changes in the sedimentation, oxygenation and nutrient availability. Miguez-Salas et al. (2017) and Rodríguez-Tovar et al. (2017) show good examples from the Lusitanian Basin with unusual behaviour and palaeobiological changes of tracemakers as a response to the T-OAE.

The study of fossil vertebrates was conducted on especially well- 
preserved specimens and facies from Canada, Germany and England (e.g., Konwert and Stumpf, 2017; Martindale et al., 2017; Vincent et al., 2017). The main studied groups were actinopterygians (Konwert and Stumpf, 2017; Maxwell and Martindale, 2017; Maxwell and Stumpf, 2017), ichthyosaurs (Plet et al., 2017) and plesiosaurs (Vincent et al., 2017).

\section{Geochemistry, Environmental Conditions and Palaeoclimatology}

Various types of geochemical analyses are progressively providing an increasing set of information and allowing us to better understand the environmental conditions governing the climate, the oceanographic circulation, the weathering intensity, and the activity of volcanism. Thus, the massive enrichment of isotopically light carbon and its transfer between the different reservoirs have been proposed as causes triggering the negative CIE of the T-OAE.

Stable isotopes geochemistry was based mainly on $\delta^{13} \mathrm{C}$ and $\delta^{18} \mathrm{O}$. Most of the analyses have been performed on bulk rock sample (e.g., Bougeault et al., 2017; Them et al., 2017a), belemnite rostra (Ait-Itto et al., 2017; Pugh et al., 2017), brachiopod shells (Ferreira et al., 2017), and organic matter (Silva et al., 2017). Also $\delta^{98 / 95}$ Mo has been studied from Central and North European sections for interpreting the incidence of euxinic conditions and water renewal during the T-OAE (Dickson et al., 2017). The osmium isotope $\left({ }^{187} \mathrm{Os} /{ }^{188} \mathrm{Os}\right.$ ) stratigraphy has been used to reconstruct the seawater composition and to approach the enhanced weathering during the T-OAE as a response to climatic warming (Them et al., 2017b).

The analysis of organic matter includes the determination of the total organic carbon (TOC), total sulfur, palynofacies and biomarkers. Some studies have focused on the reconstruction of paleoclimatology from analysing the charcoal and phytoclast abundances and palynofacies (Baker et al., 2017; Rodrigues et al., 2017; Xu et al., 2017). These works also give information about the processes happened in terrestrial environments, such as the incidence of wildfires on the $\mathrm{pO}_{2}$ (Baker et al., 2017).

\section{IGCP-655 Activities 2017}

The first steps of the project were the preparation of a website (http://igcp655-toae.com/) as well as the organization of working groups for different topics.

Some educational activities have been developed (Fig. 1) by Luís V. Duarte (Univ. Coimbra) with the collaboration of the Portuguese Association of Biology and Geology Teachers in Morocco (March 2017; co-supervised by Driss Sadki, Univ. Meknes), and Peniche GSSP (April 2017) and with the Casa das Ciências (https://www.casadasciencias.org/; July 2017). The educational and science popularization of the T-OAE recorded at Peniche was emphasized in Duarte et al. (2017).

The main activity of the IGCP-655 has been the $1^{\text {st }}$ International Workshop on the Toarcian Oceanic Anoxic Event (IW-TOAE), October 4-7 2017 in the University of Jaén (Spain) organized by the Prof. Matías Reolid (Figs. 2 and 3). The workshop brought together specialists from all over the world to share new ideas and cooperate in the study of T-OAE. Researchers coming to the IW-TOAE presented interesting advances on the study of the Toarcian Oceanic Anoxic Event, including works on different disciplines such as biostratigraphy, ichnology, palaeoecology, cyclostratigraphy. sedimentology, mineralogy, geochemistry, and biogeochemistry from regions as diverse as Maghreb, South and North Europe, Arabian Peninsula, Siberia and Himalaya. There were 38 scientific attendees, over 18 oral presentations, and 17 posters with high-quality scientific contributions, and constructive discussions, within a friendly and cooperative atmosphere during the workshop. A total of 14 young scientists attended the IW-TOAE.

The IW-TOAE meeting comprised four days of activities. The first day, October $4^{\text {th }}$, we started with a very interesting short training course on ichnology and the use for interpreting biovents by Prof. Francisco J. Rodríguez-Tovar and Dr. Javier Dorador of the University of Granada (Spain). The title of the course was "The ichnological record as a tool to assess different order bio-events". The course, for a
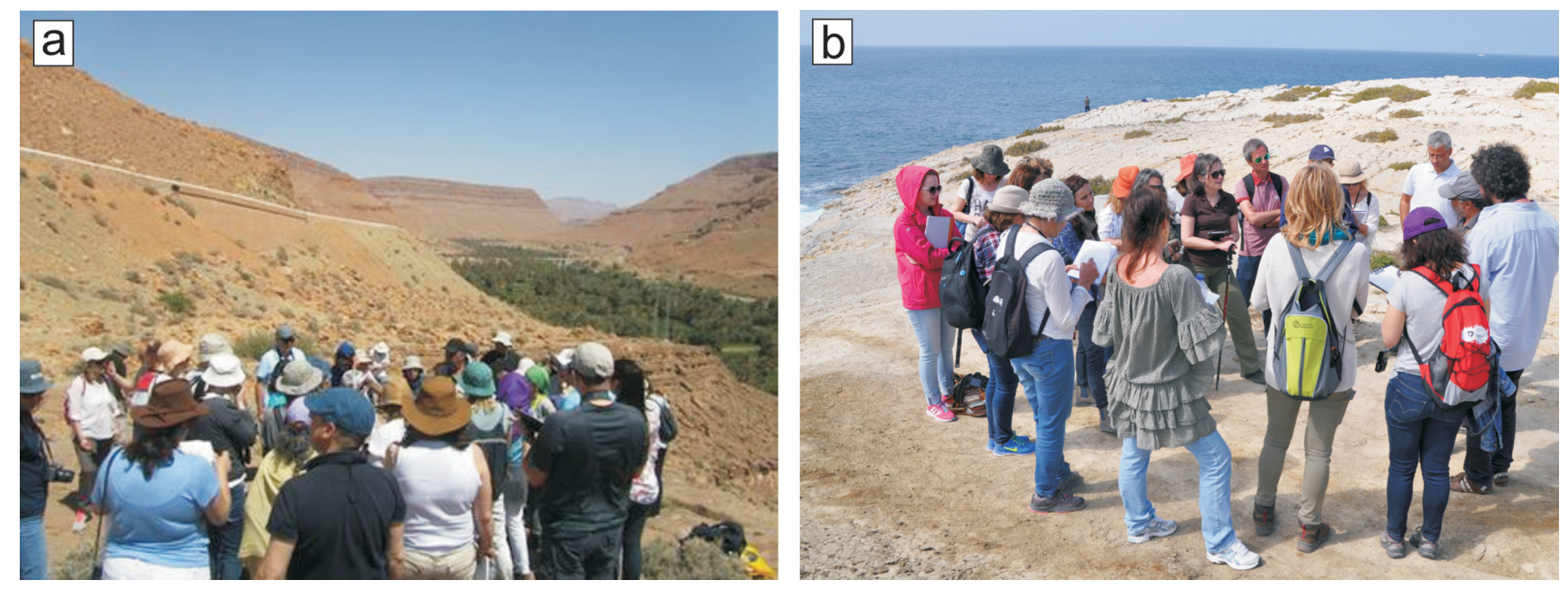

Figure 1. Educational activities for Biology and Geology High-School Teachers. (a) Visit of the Lower Jurassic of the High Atlas (Morocco) with professors Duarte (Univ. Coimbra) and Sadki (Univ. Meknes). (b) Visit of the Peniche GSSP for the Pliensbachian-Toarcian boundary, Portugal with the Professor Duarte. 

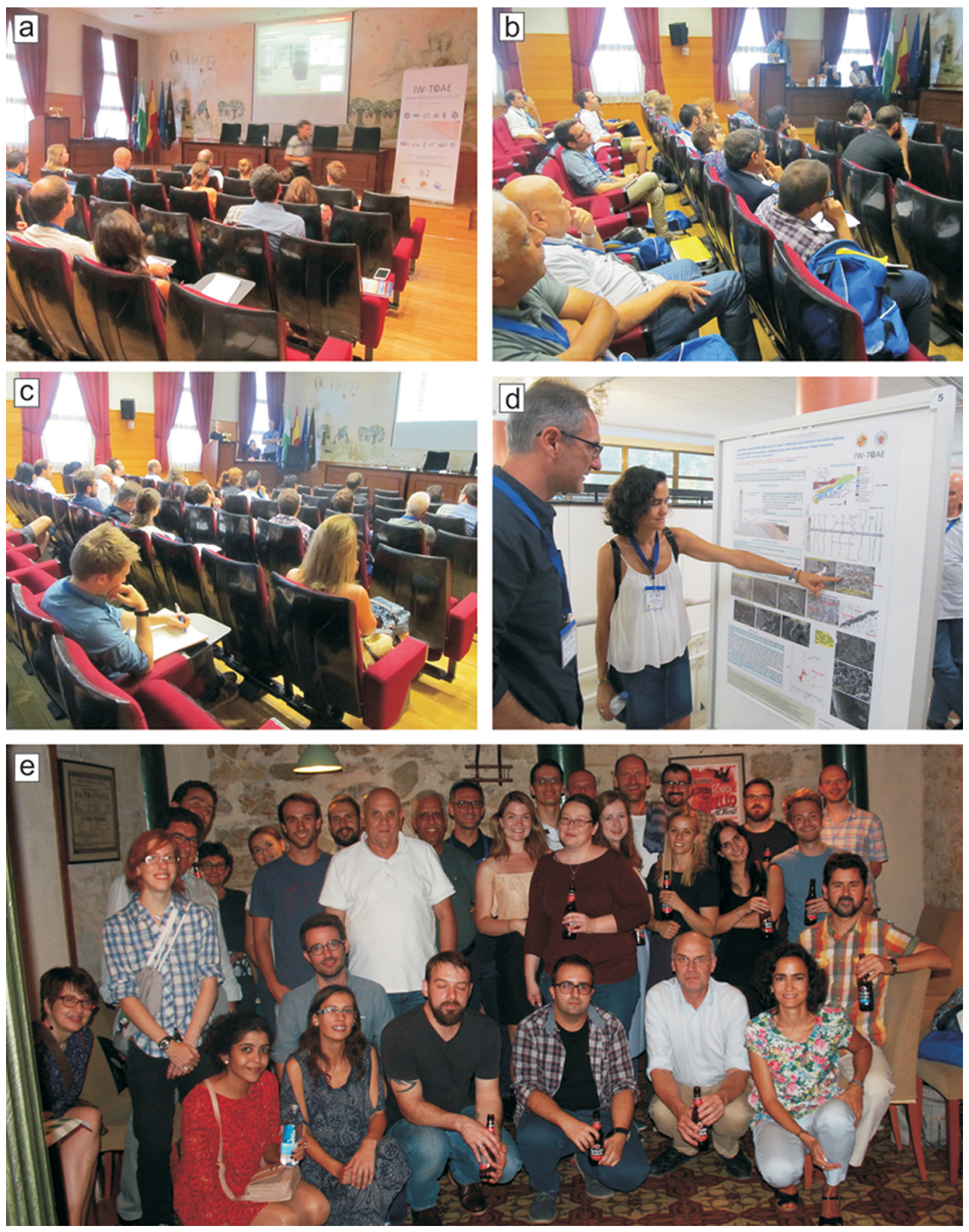

Figure 2. Activities of the IW-TOAE. (a) Prof. Francisco J. Rodriguez-Tovar (Univ. Granada) during the course on ichnology. (b) PhD student Asad Abdi (Ferdowsi Univ. Mashhad, Iran) during his oral presentation. (c) PhD student Iben Winter Hougaard (Univ. Copenhagen, Denmark) during her oral presentation. (d) Discussions during the poster session. (e) After congress social dinner.

total of 7 hours, began with a first part: An introduction to ichnology (Fig. 2a). The second part: The use to approach environmental conditions before, during and after bio-events with special interest to oceanic anoxic events included examples from the $\mathrm{K} / \mathrm{Pg}$ boundary event, the T-OAE, the OAE-1, the OAE-2 and the PETM. The last part, Digital image treatment for ichnofabric characterization in sediment cores was focused on the high resolution digital image treatment and applications with practical examples.
On October $5^{\text {th }}$ we continued with the scientific sessions as well as an invited conference by Stephen P. Hesselbo, professor of the University of Exeter (United Kingdom) titled Changing perceptions of the Toarcian Oceanic Anoxic Event; past, present and future research questions and directions. After the scientific sessions (oral and poster, Figs. 2b-d), participants enjoyed with a guided visit of the Jaén historical centre and the congress social dinner (Fig. 2e).

On October $6^{\text {th }}$, we visited the Fuente Vidriera section, a reference 

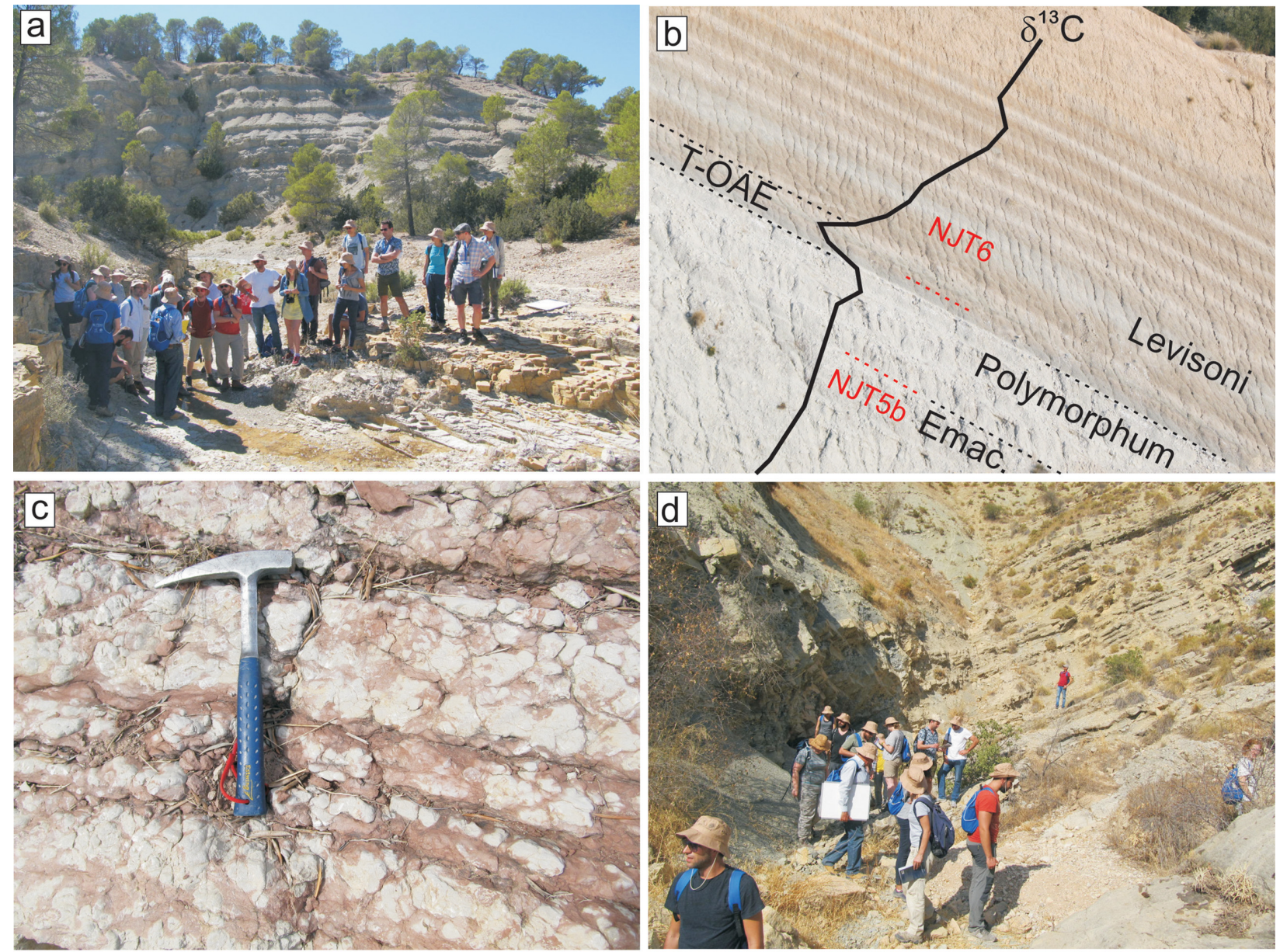

Figure 3. Field work and outcrops of the post-congress fieldtrip in the Betic Cordillera. (a) Fuente Vidriera outcrop, External Subbetic with the explanations of Prof. J.M. Molina (Univ. Jaén) about internal waves. (b) The T-OAE from La Cerradura section (External Subbetic), with the ammonite and calcareous nannofossil zones and the negative carbon isotopic excursion. (c) Ammonitico rosso facies section and the boundary of the middle and upper Toarcian of the Arroyo Mingarrón section (Median Subbetic). (d) Marl-limestone rhythmite of the Pliensbachian and lower Toarcian (Polymorphum Zone) in the Arroyo Mingarrón section.

outcrop located in the External Subbetic, Betic Cordillera (Murcia Province, Fig. 3a), where the Pliensbachian/Toarcian boundary and the T-OAE are well exposed (Rodríguez-Tovar and Uchman, 2010; Rodríguez-Tovar and Reolid, 2013). The researchers had the opportunity of sampling and having profitable discussion on the sedimentary expression of the T-OAE in this section (trace fossils, geochemical signal, $\delta^{13} \mathrm{C}$ isotope excursion, microfossil assemblages) as well as the presence of internalites in the Middle Toarcian.

On October $7^{\text {th }}$, we visited the La Cerradura section close to Jaén, External Subbetic (Fig. 3b). The attendees discussed the previously published results for this outcrop such as geochemical proxies, stable isotopes, presence of a benthic barren interval in the Serpentinum Zone (Reolid et al., 2014) and the presence of spectacular celestine nodules. We continued our excursion southwards for visiting the Iznalloz section and Arroyo Mingarrón section of the Median Subbetic, located in the Granada Province (Figs. 3c and d). These sections are a good example for illustrating the fragmentation of the Iberian palaeomargin during the middle Pliensbachian, and of the presence of epioceanic trough (with marly deposits) and swells (with ammonitico rosso facies) (Reolid et al., 2015, 2018).

The scientific and social activities during the meeting gave us many opportunities to explore new scientific networks and to share new ideas for advancing in the research on Mesozoic anoxic events. New collaborations have resulted after discussions, as well as new proposal for special sessions focused on the T-OAE in the framework of the IGCP655.

IGCP-655 project supported some young researchers for attending the IGCP-655. They came from Iran, Morocco, Algeria, Portugal and Germany.

We are organizing now the next meeting in Coimbra-Peniche (Portugal), which will be held in September 2018. The second IW-TOAE will be organized by Prof. Luís Vítor Duarte (Universidade de Coimbra) September 6-9 2018 including an Organic Matter Short Course, one day of scientific sessions and two days for fieldtrip visiting the outcrops of the Lusitanian Basin included the Peniche section (GSSP for the Pliensbachian/Toarcian boundary). 


\section{Acknowledgements}

This is a contribution of the IGCP-655 project of the IUGS and UNESCO.

\section{References}

Aberhan, M., and Fürsich, F.T., 2000, Mass origination versus mass extinction: the biological contribution to the Pliensbachian-Toarcian extinction event. Journal of the Geological Society, v. 157, pp. 55-60.

Ait-Itto, F.Z., Price, G.D., Addi, A.A., Chafiki, D., and Mannani, I., 2017, Bulk-carbonate and belemnite carbon-isotope records across the Pliensbachian-Toarcian boundary on the northern margin of Gondwana (Issouka, Middle Atlas, Morocco). Palaeogeography, Palaeoclimatology, Palaeoecology, v. 466, pp. 128-136.

Al-Suwaidi, A.H., Angelozzi, G.N., Baudin, F., Damborenea, S.E., Hesselbo, S.P., Jenkyns, H.C., Manceñido, M.O., and Riccardi, A.C., 2010, First record of the Early Toarcian Oceanic Anoxic Event from the Southern Hemisphere, Neuquén Basin, Argentina. Journal of the Geological Society, v. 167, pp. 1-4.

Bailey, T.R., Rosenthal, Y., McArthur, J.M., van de Schootbrugge, B., and Thirlwall, M.F., 2003, Paleoceanographic changes of the Late Pliensbachian-Early Toarcian interval: a possible link to the genesis of an oceanic anoxic event. Earth and Planetary Science Letters, v. 212, pp. 307-320.

Baker, S.J., Hesselbo, S.P., Lenton, T.M., Duarte, L.V., and Belcher, C.M., 2017, Charcoal evidence that rising atmospheric oxygen terminated Early Jurassic ocean anoxia. Nature Communications, v. 8, 15018. DOI: $10.1038 /$ ncomms 15018

Baeza-Carratal, J.F., Reolid, M., and García Joral, F., 2017, New deepwater brachiopod resilient assemblage from the South-Iberian Palaeomargin (western Tethys) and its significance for the brachiopod adaptive strategies around the Early Toarcian Mass Extinction Event. Bulletin of Geosciences, v. 92, pp. 233-256.

Bougeault, C., Pellenard, P., Deconinck, J.F., Hesselbo, S.P., Dommergues, J.L., Bruneau, L., Cocquerez, T., Laffont, R., Huret, E., and Thibault, N., 2017, Climatic and palaeoceanographic changes during the Pliensbachian (Early Jurassic) inferred from clay mineralogy and stable isotope (C-O) geochemistry (NW Europe). Global and Planetary Change, v. 149, pp. 139-152.

Bruneau, B., Chauveau, B., Baudin, F., and Moretti, I., 2017, 3D stratigraphic forward numerical modelling approach for prediction of organic-rich deposits and their heterogeneities. Marine and Petroleum Geology, v. 82, pp. 1-20.

Bucefalo-Palliani, R., Mattioli, E., and Riding, J.B., 2002, The response of marine phytoplankton and sedimentary organic matter to the Early Toarcian (Lower Jurassic) oceanic anoxic event in northern England. Marine Micropaleontology, v. 46, pp. 223-245.

Caruthers, A.H., Gröcke, D.R., and Smith, P.L., 2011, The significance of an Early Jurassic (Toarcian) carbon-isotope excursion in Haida Gwaii (Queen Charlotte Islands), British Columbia, Canada. Earth and Planetary Science Letters, v. 307, pp. 19-26.

Caruthers, A.H., Smith, P.L., and Gröcke, D.R., 2014, The PliensbachianToarcian (Early Jurassic) extinction: a North American perspective. In: Keller, G., and Kerr, A.C. (Eds.), Volcanism, Impacts, and Mass Extinctions: Causes and Effects. Geological Society of America, Special Paper, v. 505, pp. 225-243. DOI: 10.1130/2014.2505(11)

Caswell, B.A., and Frid, C.L.J., 2017, Marine ecosystem resilience during extreme deoxygenation: the Early Jurassic oceanic anoxic event. Oecologia, v. 183, pp. 275-290.

Cecca, F., and Macchioni, F., 2004, The two Early Toarcian (Early Jurassic) extinction events in ammonoids. Lethaia, v. 37, pp. 35-56.
Correia, V.F., Riding, J.B., Duarte, L.V., Fernandes, P., and Pereira, Z., 2017a, The palynological response to the Toarcian Oceanic Anoxic Event (Early Jurassic) at Peniche, Lusitanian Basin, western Portugal. Marine Micropaleontology, v. 137, pp. 46-63.

Correia, V.F., Riding, J.B., Fernandes, P., Duarte, L.V., and Pereira, Z., 2017b, The palynology of the lower and middle Toarcian (Lower Jurassic) in the northern Lusitanian Basin, western Portugal. Review of Palaeobotany and Palynology, v. 237, pp. 75-95.

Danise, S., Twichett, R.J., Little, C.T.S., and Clémence, M.E., 2013, The impact of global warming and anoxia on marine benthic community dynamics: an example from the Toarcian (Early Jurassic). PLoS ONE, v. 8, e56255. DOI: 10.1371/journal.pone.0056255

De Graciansky, P.-C., Jacquin, T., and Hesselbo, S.P., 1999, The Ligurian cycle: an overview of Lower Jurassic $2^{\text {nd }}$-order transgressive/regressive facies cycles in western Europe. In: De Graciansky, P.-C., Hardenbol, J., Jacquin, T., and Vail, P.R. (Eds.), SEPM, Special Publication, v. 60, pp. 467-479.

Dickson, A.J., Gill, B.C., Ruhl, M., Jenkyns, H.C., Porcelli, D., Idiz, E., Lyons, T.W., and van den Boorn, S.H.J.M., 2017, Molybdenum-isotope chemostratigraphy and paleoceanography of the Toarcian Oceanic Anoxic Event (Early Jurassic). Paleoceanography, v. 32, pp. 813-829. DOI: 10.1002/2016PA003048

Duarte, L.V, Silva, R.L., Félix, F., Comas-Rengifo, M.J., Rocha, R.B., Mattioli, E., Paredes, R., Mendonça Filho, J.G., and Cabral, M.C., 2017, The Jurassic of the Peniche Peninsula (Portugal): scientific, educational and science popularization relevance. Revista de la Sociedad Geológica de España, v. 30, pp. 55-70.

Ferreira, J., Mattioli, E., and van de Schootbrugge, B., 2017, Palaeoenvironmental vs. evolutionary control on size variation of coccoliths across the Lower-Middle Jurassic. Palaeogeography, Palaeoclimatology, Palaeoecology, v. 465, pp. 177-192.

García Joral, F., Gómez, J.J., and Goy, A., 2011, Mass extinction and recovery of the Early Toarcian (Early Jurassic) brachiopods linked to climate change in northern and central Spain. Palaeogeography, Palaeoclimatology, Palaeoecology, v. 302, pp. 367-380.

Ghadeer, S.G., and Macquaker, J.H.S., 2011, Sediment transport processes in an ancient mud-dominated succession: a comparison of processes operating in marine offshore settings and anoxic basinal environments. Journal of the Geological Society, v. 168, pp. 1121-1132.

Glinskikh, L., Radevich, A., and Nikitenko, B.L., 2017, Foraminifera and geochemistry of the Upper Pliensbachian-Lower Toarcian in different facial sections of the NE Siberia. Proceedings of the $1^{\text {st }}$ International Workshop on the Toarcian Oceanic Anoxic Event (IW-TOAE): Impact on Marine Carbon Cycle and Ecosystems, IGCP-655, Jaén, pp. 63-65.

Gómez, J.J., and Goy, A., 2011, Warming-driven mass extinction in the Early Toarcian (Early Jurassic) of northern and central Spain. Correlation with other time-equivalent European sections. Palaeogeography, Palaeoclimatology, Palaeoecology, v. 306, pp. 176-195.

Haq, B.U., Hardenbol, J., and Vail, P.R., 1987, Chronology of fluctuating sea-levels since the Triassic. Nature, v. 235, pp. 1156-1167.

Hallam, A., 1987, Radiations and extinctions in relation to environmental change in the marine Lower Jurassic of northwest Europe. Paleobiology, v. 13, pp. 152-168.

Han, Z., Hu, X., Kemp, D., and Li, J., 2017, Carbonate platform response to the Toarcian Oceanic Anoxic Event in the Tibetan Himalaya: implications for environmental change and biotic platform demise. Proceedings of the $1^{\text {st }}$ International Workshop on the Toarcian Oceanic Anoxic Event (IW-TOAE): Impact on Marine Carbon Cycle and Ecosystems, IGCP-655, Jaén, pp. 67-68.

Hermoso, M., Le Callonnec, L., Minoletti, F., Renard, M., and Hesselbo, S.P., 2009, Expression of the Early Toarcian negative carbon-isotope excursion in separated carbonate microfractions (Jurassic, Paris Basin). Earth and Planetary Science Letters, v. 277, pp. 194-203.

Herrero, C., 2017, Early Toarcian foraminiferal events in the Central Sector of the Iberian Range (Spain) where neither black shales nor foraminifera 
mass extinction are recorded. Proceedings of the $1^{\text {st }}$ International Workshop on the Toarcian Oceanic Anoxic Event (IW-TOAE): Impact on Marine Carbon Cycle and Ecosystems, IGCP-655, Jaén, pp. 69-71.

Hesselbo, S.P., Gröcke, D.R., Jenkyns, H.C., Bjerrum, C.J., Farrimond, P., Morgans Bell, H.S., and Green, O.R., 2000, Massive dissociations of gas hydrate during a Jurassic oceanic anoxic event. Nature, v. 406, pp. 392-395.

Hesselbo, S.P., Jenkyns, H.C., Duarte, L.V., and Oliveira, L.C.V., 2007, Carbon-isotope record of the Early Jurassic (Toarcian) Oceanic Anoxic Event from fossil wood and marine carbonate (Lusitanian Basin, Portugal). Earth and Planetary Science Letters, v. 253, pp. 455-470.

Izumi, K., Miyaji, T., and Tanabe, K., 2012, Early Toarcian (Early Jurassic) oceanic anoxic event recorded in the shelf deposits in the northwestern Panthalassa: evidence from the Nishinakayama formation in the Toyora area, west Japan. Palaeogeography, Palaeoclimatology, Palaeoecology, v. 315-316, pp. 100-108.

Jenkyns, H.C., 1988, The early Toarcian (Jurassic) anoxic event: stratigraphic, sedimentary and geochemical evidence. American Journal of Science, v. 288, pp. 101-151.

Jenkyns, H.C., and Clayton, C.J., 1986, Black shales and carbon isotopes in pelagic sediments from the Tethyan Lower Jurassic. Sedimentology, v. 33, pp. 87-106.

Kemp, D.B., Coe, A.L., Cohen, A.S., and Schwark, L., 2005, Astronomical pacing of methane release in the Early Jurassic period. Nature, v. 437, pp. 396-399.

Konwert, M., and Stumpf, S., 2017, Exceptionally preserved Leptolepidae (Actinopterygii, Teleostei) from the late Early Jurassic FossilLagerstatten of Grimmen and Dobbertin (Mecklenburg-Western Pomerania, Germany). Zootaxa, v. 4243, pp. 249-296.

Korte, C., and Hesselbo, S.P., 2011, Shallow marine carbon and oxygen isotope and elemental records indicate icehouse-greenhouse cycles during the early Jurassic. Paleoceanography, v. 26, PA4219. https:// doi.org/10.1029/2011PA002160

Little, C.T.S., and Benton, M.J., 1995, Early Jurassic mass extinction: a global long-term event. Geology, v. 23, pp. 495-498.

Martindale, R.C., Them, T.R., Gill, B.C., Marroquin, S.M., and Knoll, A.H., 2017, A new Early Jurassic (ca. $183 \mathrm{Ma}$ ) fossil Lagerstatte from Ya Ha Tinda, Alberta, Canada. Geology, v. 45, pp. 255-258.

Martindale, R.C., and Aberhan, M., 2017, Response of macrobenthic communities to the Toarcian Oceanic Anoxic Event in northeastern Panthalassa (Ya Ha Tinda, Alberta, Canada). Palaeogeography, Palaeoclimatology, Palaeoecology, v. 478, pp. 103-120.

Martinez, M., Krencker, F.N., Mattioli, E., and Bodin, S., 2017, Orbital chronology of the Pliensbachian-Toarcian transition from the Central High Atlas Basin (Morocco). Newsletters on Stratigraphy, v. 50, pp. 47-69.

Maxwell, E.E., and Martindale, R.C., 2017, New Saurorhynchus (Actinopterygii: Saurichthyidae) material from the Early Jurassic of Alberta, Canada. Canadian Journal of Earth Sciences, v. 54, pp. 714-719.

Maxwell, E.E., and Stumpf, S., 2017, Revision of Saurorhynchus (Actinopterygii: Saurichthyidae) from the Early Jurassic of England and Germany. European Journal of Taxonomy, v. 321, pp. 1-29.

McArthur, J.M., Donovan, D.T., Thirvall, M.F., Fouke, B.W., and Mattey, D., 2000, Strontium isotope of the Early Toarcian (Jurassic) oceanic anoxic event, the duration of ammonite biozones and belemnite palaeotemperatures. Earth and Planetary Science Letters, v. 179, pp. 269285 .

McArthur, J.M., Algeo, T.J., van de Schootbrugge, B., Li, Q., and Howarth, R.J., 2008, Basinal restriction, black shales, Re-Os dating, and the Early Toarcian (Jurassic) oceanic anoxic event. Paleoceanography 23, PA4217. https://doi.org/10.1029/2008PA001607

McElwain, J.C., Wade-Murphy, J., and Hesselbo, S.P., 2005, Changes in carbon dioxide during an anoxic event linked to intrusion of Gondwana coals. Nature, v. 435, pp. 479-482.

Miguez-Salas, O., Rodríguez-Tovar, F.J., and Duarte, L.V., 2017, Selec- tive incidence of the Toarcian oceanic anoxic event on macroinvertebrate marine communities: a case from the Lusitanian basin, Portugal. Lethaia, v. 50, pp. 548-560.

Molnar, Z., Polgari, M., Hein, J.R., Jozsa, S., Fekete, J., Gyollai, I., Fintor, K., Biro, L., Szabo, M., Rapi, S., Forgo, P., and Vigh, T., 2017, Fe-Mn oxide indications in the feeder and mound zone of the Jurassic Mn-carbonate ore deposit, Urkut, Hungary. Ore Geology Reviews, v. 86, pp. 839-855.

Molina, J.M., Nieto, L.M., and Reolid, M., 2017, Calcareous tempestites and internalites in the Toarcian of the Subbetic (Betic Cordillera, Spain). Proceedings of the $1^{\text {st }}$ International Workshop on the Toarcian Oceanic Anoxic Event (IW-TOAE): Impact on Marine Carbon Cycle and Ecosystems, IGCP-655, Jaén, pp. 83-85.

Monarrez, P.M., Aberhan, M., and Holland, S.M., 2017, Regional and environmental variation in escalatory ecological trends during the Jurassic: a western Tethys hotspot for escalation? Paleobiology, v. 43, pp. 569-586.

Piazza, V., Aberhan, M., and Duarte, L.V., 2017, Body size trends of brachiopods and bivalves at the early Toarcian (Early Jurassic) extinction event in tue Lusitanian Basin, Portugal. Proceedings of the $1^{\text {st }}$ International Workshop on the Toarcian Oceanic Anoxic Event (IW-TOAE): Impact on Marine Carbon Cycle and Ecosystems, IGCP-655, Jaén, pp. 87-89.

Plet, C., Grice, K., Pages, A., Verrall, M., Coolen, M.J.L., Ruebsam, W., Rickard, W.D.A., and Schwark, L., 2017, Palaeobiology of red and white blood cell-like structures, collagen and cholesterol in an ichthyosaur bone. Scientific Reports, v. 7, 13776. https://doi.org/10.1038/s41598017-13873-4

Posenato, R., Bassi, D., Trecalli, A., and Parente, M., 2017, Taphonomy and evolution of Lower Jurassic lithiotid bivalve accumulations in the Apennine Carbonate Platform (southern Italy). Palaeogeography, Palaeoclimatology, Palaeoecology. http://dx.doi.org/10.1016/j.palaeo.2017.10.017

Pugh, A.C, Little, C.T.S., Wignall, P.B., Newton, R.J., Savov, I., Metodiev, L., Riding, J.B., and Korte, C., 2017, The Lower Jurassic $\delta^{13} \mathrm{C}$ and $\delta^{18} \mathrm{O}$ curves, from the easterly margin of the epicontinental Tethys Ocean (Balkan Mountains, NW Bulgaria). Proceedings of the $1^{\text {st }}$ International Workshop on the Toarcian Oceanic Anoxic Event (IW-TOAE): Impact on Marine Carbon Cycle and Ecosystems, IGCP-655, Jaén, pp. 91-92.

Reolid, M., 2014, Stable isotopes on foraminifera and ostracods for interpreting incidence of the Toarcian Oceanic Anoxic Event in Westernmost Tethys: role of water stagnation and productivity. Palaeogeography, Palaeoclimatology, Palaeoecology, v. 395, pp. 77-91.

Reolid, M. (Ed.), 2017, Abstract Book, $1^{\text {st }}$ International Workshop on the Toarcian Oceanic Anoxic Event (IW-TOAE): Impact on Marine Carbon Cycle and Ecosystems, IGCP-655, Jaén, 128 p.

Reolid, M., Rodríguez-Tovar, F.J., Marok, A., and Sebane, A., 2012, The Toarcian Oceanic Anoxic Event in the Western Saharan Atlas, Algeria (North African Paleomargin): role of anoxia and productivity. Geological Society of America Bulletin, v. 124, pp. 1646-1664.

Reolid, M., Mattioli, E., Nieto, L.M., and Rodríguez-Tovar, F.J., 2014, The Early Toarcian Ocanic Anoxic Event in the External Subbetic (Southiberian Palaeomargin, Westernmost Tethys): geochemistry, nannofossils and ichnology. Palaeogeography, Palaeoclimatology, Palaeoecology, v. 411, pp. 79-94.

Reolid, M., Molina, J.M., Nieto, L.M., and Rodríguez-Tovar, F.J., 2018, The Toarcian Oceanic Anoxic Event in the South Iberian Palaeomargin. SpringerBriefs in Earth Sciences, 122 p.

Reolid, M., Rivas, P., and Rodríguez-Tovar, F.J., 2015, Toarcian ammonitico rosso facies from the South Iberian Paleomargin (Betic Cordillera, southern Spain): paleoenvironmental reconstruction. Facies, v. 61, pp. 22. https://doi.org/10.1007/s10347-015-0447-3

Rita, P., Reolid, M., and Duarte, L.V., 2016, Benthic foraminiferal assemblages record major environmental perturbations during the Late Pliensbachian-Early Toarcian interval in the Peniche GSSP, Portugal. 
Palaeogeography, Palaeoclimatology, Palaeoecology, v. 454, pp. 267-281.

Rita, P., de Baets, K., and Duarte, L.V., 2017a, Body size dynamics of belemnite during the Uppermost Pliensbachian-Early Toarcian from the Peniche section (Lusitanian Basin, Portugal). Proceedings of the $1^{\text {st }}$ International Workshop on the Toarcian Oceanic Anoxic Event (IWTOAE): Impact on Marine Carbon Cycle and Ecosystems, IGCP-655, Jaén, pp. 97-98.

Rita, P., Reolid, M., and Duarte, L.V., 2017b, Test-size changes in foraminifera during the T-OAE in the Peniche section (Lusitanian Basin). Resúmenes 33 Jornadas de Paleontología, Cádiz, pp. 153-155.

Rocha, R.B., Mattioli, E., Duarte, L.V., Pittet, B., Elmi, S., Mouterde, R., Cabral, M.C., Comas-Rengifo, M.J., Gómez, J.J., Goy, A., Hesselbo, S.P., Jenkyns, H.C., Littler, K., Mailliot, S., Oliveira, L.C.V., Osete, M.L., Perilli, N., Pinto, S., Ruget, C., Suan, G., 2016, Base of the Toarcian Stage of the Lower Jurassic defined by the Global Boundary Stratotype Section and Point (GSSP) at the Peniche section (Portugal). Episodes, v. 39, pp. 460-481. DOI: 10.18814/epiiugs/2016/v39i3/99741

Rodrigues, B., Duarte, L.V., Mendonça Filho, J.G., Santos, L.G., and Oliveira, A.D. 2016, Evidence of terrestrial organic matter deposition across the early Toarcian recorded in the northern Lusitanian Basin, Portugal. International Journal of Coal Geology, v. 168, pp. 35-45.

Rodrigues, B., Silva, R.L., Duarte, L.V., Sadki, D., Wach, G., and Mendoça Filho, J.G., 2017, Abundance of fossil charcoal across the Early Toarcian Oceanic Anoxic Event in the Foum Tillicht section, Central High Atlas Basin (Morocco). Proceedings of the $1^{\text {st }}$ International Workshop on the Toarcian Oceanic Anoxic Event (IW-TOAE): Impact on Marine Carbon Cycle and Ecosystems, IGCP-655, Jaén, pp. 99-100.

Rodríguez-Tovar, F.J., and Reolid, M., 2013, Environmental conditions during the Toarcian Oceanic Anoxic Event (T-OAE) in the westernmost Tethys: influence of the regional context on a global phenomenon. Bulletin of Geosciences, v. 88, pp. 697-712.

Rodríguez-Tovar, F.J., and Uchman, A., 2010, Ichnofabric evidence for the lack of bottom anoxia during the Lower Toarcian Oceanic Anoxic Event (T-OAE) in the Fuente de la Vidriera section, Betic Cordillera, Spain. Palaios, v. 25, pp. 576-587.

Rodríguez-Tovar, F.J., Miguez-Salas, O., and Duarte, L.V., 2017, Toarcian Oceanic Anoxic Event induced unusual behaviour and palaeobiological changes in Thalassinoides tracemakers. Palaeogeography, Palaeoclimatology, Palaeoecology, v. 485, pp. 46-56. https://doi.org/10.1016/ j.palaeo.2017.06.002

Röhl, H.J., Schmid-Röhl, A., Oschmann, W., Frimmel, A., and Schwark, L., 2001, The Posidonia Shale (Lower Toarcian) of SW-Germany: an oxygen-depleted ecosystem controlled by sea level and palaeoclimate. Palaeogeography, Palaeoclimatology, Palaeoecology, v. 165, pp. 27-52.

Ruebsam, W., and Schwark, L., 2017, Phytoplankton community dynamics during the Early Toarcian Oceanic Anoxic Event deduced from high-resolution biomarker investigation. Proceedings of the $1^{\text {st }}$ International Workshop on the Toarcian Oceanic Anoxic Event (IW-TOAE): Impact on Marine Carbon Cycle and Ecosystems, IGCP-655, Jaén, pp. 101-102.

Ruhl., M., Hesselbo, S.P., Xu, W., Thibaoult, N., Jenkyns, H.C., Al Suwaidi, A., Storm, M., Riding, J.B., and Ullmann, C.V., 2017, A high-precision numerical time-scale for the Toarcian Stage: implications for timing of the marine Toarcian Oceanic Anoxic Event (T-OAE) and KarooFerrar volcanism. Proceedings of the $1^{\text {st }}$ International Workshop on the Toarcian Oceanic Anoxic Event (IW-TOAE): Impact on Marine Carbon Cycle and Ecosystems, IGCP-655, Jaén, pp. 103-105.

Sebane, A., and Touahria, A., 2017, Palaeoenvironment and morphology of the foraminifera of the Upper Domerian-Lower Toarcian of Benia (Tiaret, Western Algeria). Proceedings of the $1^{\text {st }}$ International Workshop on the Toarcian Oceanic Anoxic Event (IW-TOAE): Impact on Marine Carbon Cycle and Ecosystems, IGCP-655, Jaén, pp. 111-112.
Silva, R.L., Carlisle, C.A.M., and Wach, G., 2017, A new TOC, rock-eval, and carbon isotope record of Lower Jurassic source rocks from the Slyne Basin, offshore Ireland. Marine and Petroleum Geology, v. 86, pp. 499-511.

Schouten, S., van Kaam-Peters, H.M.E., Rijpstra, W.I.C., Schoell, M., and Sinninghe Damst, J.S., 2000, Effects of an oceanic anoxic event on the stable carbon isotopic composition of early Toarcian carbon. American Journal of Science, v. 300, pp. 1-22.

Soulimane, C., Reolid, M., and Marok, A., 2017, Ostracod assemblages from the uppermost Pliensbachian and Lower Toarcian of the Traras Mountains (Tlemcen Domain, north Algeria). Arabian Journal of Geosciences, v. 10, pp. 393. https://doi.org/10.1007/s12517-017-3180-0

Soulimane, C., Reolid, M., Rita, P., Marok, A., and Duarte, L.V., 2017, Uppermost Pliensbachian-lowermost Toarcian ostracod assemblages from the Western Tethys: comparison between Traras Mountains (Algeria), Subbetic (Spain), and Algarve (Portugal). Annales de Paléontologie, v. 103, pp. 251-269. https://doi.org/10.1016/j.annpal.2017.10.002

Suan, G., Nikitenko, B.L., Rogov, M.A., Baudin, F., Spangenberg, J.E., Knyazev, V.G., Glinskikh, L.A., Goryacheva, A.A., Adatte, T., Riding, J.B., Föllmi, K.B., Pittet, B., Mattioli, E., and Lécuyer, C., 2011, Polar record of Early Jurassic massive carbon injection. Earth and Planetary Science Letters, v. 312, pp. 102-113.

Them, T.R., Gill, B.C., Caruthers, A.H., Grocke, D.R., Tulsky, E.T., Martindale, R.C., Poulton, T.P., and Smith, P.L., 2017a, High-resolution carbon isotope records of the Toarcian Oceanic Anoxic Event (Early Jurassic) from North America and implications for the global drivers of the Toarcian carbon cycle. Earth and Planetary Science Letters, v. 459, pp. 118-126.

Them, T.R., Gill, B.C., Selby, D., Grocke, D.R., Friedman, R.M., and Owens, J.D., 2017b, Evidence for rapid weathering response to climatic warming during the Toarcian Oceanic Anoxic Event. Scientific Reports, v. 7, pp. 5003. https://doi.org/10.1038/s41598-017-05307-y

Ullman, C.V., Thibault, N., Ruhl, M., Hesselbo, S.P., and Korte, C., 2014, Effect of a Jurassic Oceanic Anoxic Event on belemnite ecology and evolution. Proceedings of the National Academy of Sciences, v. 111, pp. 10073-10076.

Val, J., Badenas, B., Aurell, M., and Rosales, I., 2017, Cyclostratigraphy and chemostratigraphy of a bioclastic storm-dominated carbonate ramp (late Pliensbachian, Iberian Basin). Sedimentary Geology, v. 355, pp. 93-113.

Vincent, P., Allemand, R., Taylor, P.D., Suan, G., and Maxwell, E.E., 2017, New insights on the systematics, palaeoecology and palaeobiology of a plesiosaurian with soft tissue preservation from the Toarcian of Holzmaden, Germany. Science of Nature, v. 104, pp. 5-6.

Visentin, S., Reolon, D., Faucher, G., and Erba, E., 2017, Calcareous annofossil biostratigraphy and paleoceanography across the Toarcian Oceanic Anoxic Event cored at Colle di Sogno (Lombardy Basin, Northern Italy). Proceedings of the $1^{\text {st }}$ International Workshop on the Toarcian Oceanic Anoxic Event (IW-TOAE): Impact on Marine Carbon Cycle and Ecosystems, IGCP-655, Jaén, pp. 125-126.

Vörös, A., 2002, Victims of the Early Toarcian anoxic event: the radiation and extinction of Jurassic Koninckinidae (Brachiopoda). Lethaia, v. 35, pp. 345-357.

Wignall, P.B., Newton, R.J., and Little, C.T.S., 2005, The timing of paleoenvironmental change and cause-and-effect relationships during the Early Jurassic mass extinction in Europe. American Journal of Science, v. 305, pp. 1014-1032.

Xu, W., Ruhl, M., Jenkyns, H.C., Hesselbo, S.P., Riding, J.B., Selby, D., Naafs, B.D.A., Weijers, J.W.H., Pancost, R.D., Tegelaar, E., and Idiz, E., 2017, Carbon sequestration in an expanded lake system during the Toarcian oceanic anoxic event. Nature Geoscience, v. 10, pp. 129-134. https://doi.org/10.1038/ngeo2871 